\title{
Special Status Fishes Strategy for California Desert District
}

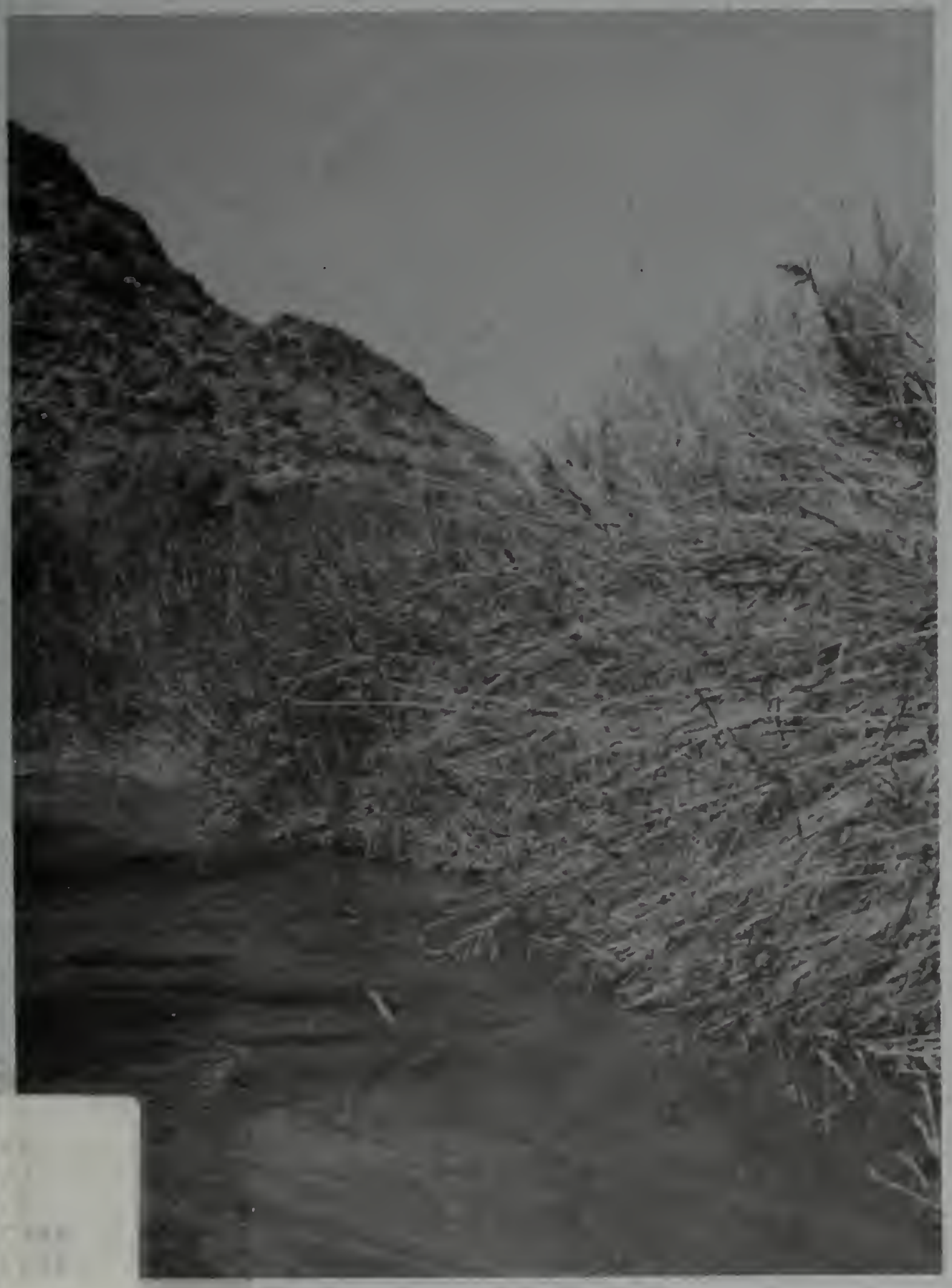

California Desert District Fish \& Wildlife 2000 Series

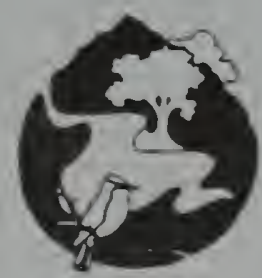




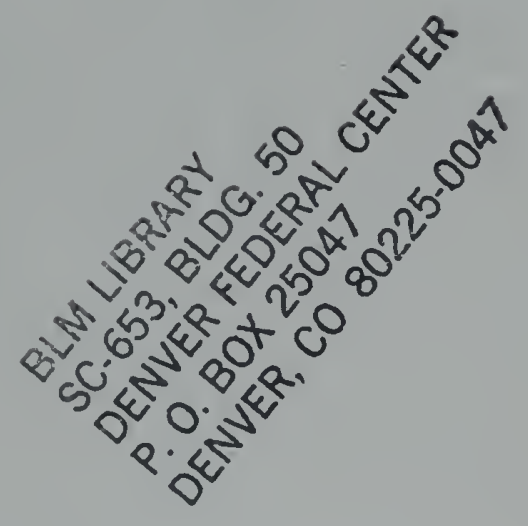

BLM/CA/PL-94/012+6500

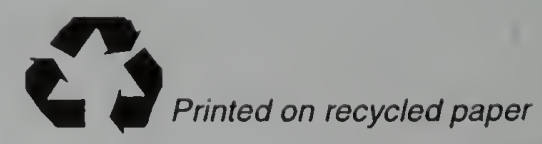


BLM LIBRARY

SC. 653 , BLDG. 50

DENVER FEDERAL CEㄱITER

P. O. BOX 25047

DENVER, CO 80225-0047

\section{SPECIAL STATUS FISHES}

\section{STRATEGY FOR}

\section{CALIFORNIA DESERT DISTRICT}

May 1994

Prepared by

CALIFORNIA DESERT DISTRICT

BUREAU OF LAND MANAGEMENT 
Cover photo: The Amargosa River pupfish and Amargosa Canyon speckled dace, both BLM sensitive species, are found in Amargosa Canyon. 
APPROVAL PAGE

SPECIAL STATUS FISHES

STRATEGY FOR

CALIFORNIA DESERT DISTRICT

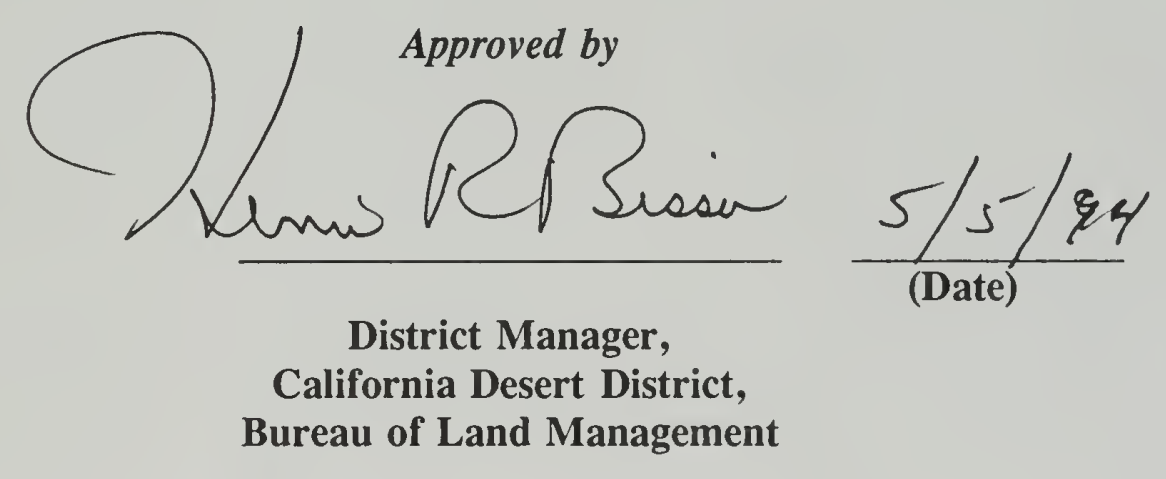




\section{CONTENTS}

Section

Page

Title Page

Approval Page

Table of Contents

i

Table of contents

INTRODUCTION

DESCRIPTION OF SPECIAL STATUS FISHES AND HABITATS Mohave Tui Chub

Desert Pupfish

Amargosa River Pupfish

Amargosa Canyon Speckled Dace

CURRENT AND RECENT MANAGEMENT PROGRAMS

Existing Management Plans and Recovery Plans

Recent Habitat Enhancement and Protection

Past Relocation Efforts

MAJOR ISSUES

Mohave Tui Chub

Desert Pupfish

17

Amargosa River Pupfish and Amargosa Canyon Speckled Dace

GOALS

POLICY GUIDELINES AND STANDARDS

PLANNED ACTIONS

Mohave Tui Chub

Desert Pupfish

25

Amargosa River Pupfish and Amargosa Canyon Speckled Dace

PROGRAM COORDINATION 


\section{INTRODUCTION}

The purpose of this strategy is to set forth the general approach to management of each special status fish species in the California Desert District, to establish priorities for management action, and to provide a coordinated approach to special status fishes in the District. This document is tiered off of the Fish and Wildlife 2000 National Strategy Plan entitled "Special Status Fishes Habitat Management" (BLM 1991a) prepared by a team of biologists and managers in 1991. The National Strategy Plan gave general guidance for conserving rare fishes on lands administered by the Bureau of Land Management (BLM) in 11 western states. It described current management actions and established objectives, specific strategies, and general guidance.

The California Desert District has four special status fishes. The Mohave tui chub (Gila bicolor mohavensis) is native to the Mojave River drainage and is both a Federal and State-listed endangered species. The desert pupfish (Cyprinodon macularius) is found in the Sonoran Desert of California, Arizona, and Mexico; it is also both a Federal and State-listed endangered species. The Amargosa River pupfish (Cyprinodon nevadensis amargosae) and Amargosa Canyon speckled dace (Rhinichthys osculus nevadensis) are restricted to the Amargosa River and tributaries around Tecopa. Both are listed as BLM-sensitive in California.

The California Desert Conservation Area (CDCA) Plan (BLM 1980) established five Areas of Critical Environmental Concern to protect the habitat of these four species.

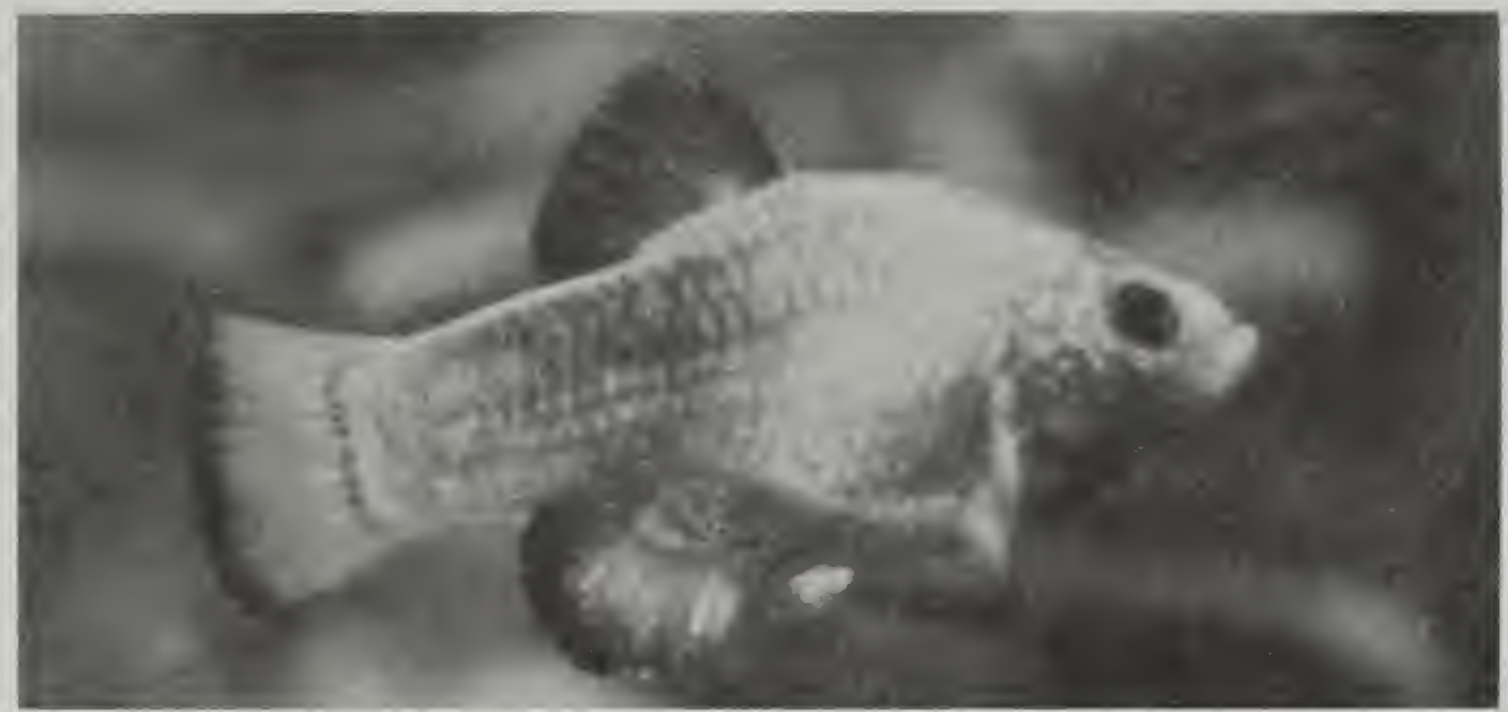

In California, the desert pupfish is found in the Salton Sink area. 


\section{DESCRIPTION OF SPECIAL STATUS FISHES AND HABITATS}

\section{Mohave Tui Chub}

Tui chub are found in most isolated drainage systems in California, Oregon, and Nevada. Since the species is genetically very plastic, there has been considerable confusion and disagreement over the taxonomic relationships among the various populations. The Mohave tui chub has long been considered a distinct form (i.e. subspecies) and has been considered a full species by some (Moyle 1976). The species is in the minnow family (Cyprinidae).

The Mohave tui chub was listed as an endangered species by the U. S. Fish and Wildlife Service on 13 October 1970. The State Fish and Game Commission listed the species as endangered in 1971.

Moyle (1976) considered tui chubs to be opportunistic omnivores which concentrate on invertebrates associated with the bottom or aquatic vegetation. Mohave tui chub overwinter in a torpid state on the bottom (Vicker 1973). Most spawning takes place in March through May after waters warm up (Vicker 1973). The eggs, which are laid on aquatic plants or the bottom, hatch in less than nine days (Moyle 1976).

Tui chub are known mostly from weedy shallows of lakes or quiet areas of slowmoving rivers. However, various forms of the species do well in a wide variety of habitat types. Historically, Mohave tui chub were found only in the Mojave River drainage. Mohave tui chub have hybridized readily with arroyo chub (G. orcutti), which is considered a full species. Miller (1968) asserted that arroyo chub were introduced into reservoirs in the headwaters of the Mojave River in the 1930's and that they had hybridized with Mohave tui chub in the river by the late 1960's.

Presently, populations of Mohave tui chub inhabit one natural spring pool (MC Spring) and one artificial pond (Lake Tuendae) at Soda Springs, a small artificial pool at the Barstow Desert Information Center (formerly Barstow Way Station), two artificial pools adjacent to the Mojave River at the Camp Cady Wildlife Area, and lagoons fed by Lark Seep on the Naval Weapons Center in Ridgecrest. Until about 1986, Mohave tui chub also were present in West Pond, an artificial pond, at the Soda Springs site.

The habitats managed by the BLM are at Soda Springs, lying on the western shore of Soda Dry Lake and at the eastern edge of the Soda Mountains. The area was 
designated an Area of Critical Environmental Concern in 1980. The facility is administered jointly by the BLM and the Desert Studies Consortium, a cooperative of nine state universities. The Consortium has a permanent, on-site caretaker.

Lake Tuendae provides habitat for a healthy population of more than 3,000 Mohave tui chub with a wide range of size and age classes. Lake Tuendae is a small, rectangular pond about 150 meters by 40 meters in size. It is an artificial pond which loses water through evaporation and seepage. The water is replenished from a nearby well using diesel operated pumps; water is pumped into the pond through a fountain which provides aeration. The pond must be dredged periodically to remove wind blown sediment and vegetative detritus. Saratoga Springs pupfish (Cyprinodon nevadensis nevadensis) also inhabits Lake Tuendae; it was apparently established by introduction from Saratoga Springs in Death Valley about 1950 (Turner and Liu 1976).

MC Spring, a natural spring and pool of about 5 meters diameter provides habitat for a small population of about 150 Mohave tui chub. Cattails (Typha domingensis) must be removed periodically around the perimeter to prevent encroachment into the pool.

West Pond (also known as Three Bats Pond) once contained a large population of Mohave tui chub, but these fish died out completely in 1985. An artificial impoundment, the pond is fed by underground spring(s). The pond is about 70 meters by 60 meters. There is little seepage since the pond is below water table level; most water loss is by evaporation. This resulted in a pond which accumulated dissolved salts and other contaminants. The pond was deepened and enlarged in 1982. However, subsequent blooms of ditchgrass (Ruppia maritima) resulted in an accumulation of ammonia as plants died back and decomposed in the fall each year. As contaminants increased and oxygen levels declined, the population declined and eventually died out. The pond has been recently (1992) dredged to inhibit plant growth and decrease surface to volume ratio. Efforts are also underway to develop a water intake/outlet. When this is completed, a population of Mohave tui chub will be reestablished.

Two ponds have been developed at the Camp Cady Wildlife Area adjacent to the Mojave River. The area is owned and administered by the California Department of Fish and Game (CDFG). Development of the ponds in the last few years has met with difficulties from seepage, but persistence has led to the establishment of two populations.

A small lagoon formed by Lark Seep on the Naval Weapons Center near Ridgecrest has a substantial population. However, the ponds and surrounding marsh are maintained by wastewater runoff. The City is under directive to limit the input. The long-term maintenance of the population is unknown. 
A small population was established at one of two ponds at the Desert Research Station of the Barstow Unified School District (BUSD) near Hinckley in the late 1970's. The site is located on BLM administered lands leased to BUSD under the Recreation and Public Purposes Act. In 1991, the Station was closed, and the ponds dried up. At the present time, no Mohave tui chub inhabit the site.

\section{Desert Pupfish}

Historically, desert pupfish were found in various streams and rivers in the Sonoran Desert of southeastern California, southwestern Arizona, northeastern Baja California, and northern Sonora. In the United States today, populations are found around the periphery of the Salton Sea and two tributaries and in artificial ponds at several sites in California and Arizona. The species has numerous near relatives found throughout the southwest. The desert pupfish is in the killifish family (Cyprinodontidae). (Moyle 1976)

The State Fish and Game Commission listed the desert pupfish as endangered in 1980. The species was listed as endangered by the U. S. Fish and Wildlife Service on March 31,1986 . Critical habitat was also designated, including, in California, 8.5 miles of San Felipe Creek upstream from Highway 86, 1.75 miles of Carrizo Wash above the confluence with San Felipe Creek, and 0.75 miles of Fish Creek Wash above the confluence with San Felipe Creek.

Desert pupfish inhabit streams, artificial ponds and pools, irrigation drains emptying into the Salton Sea, and shoreline pools of the Salton Sea. The species is tolerant of an exceptional range of salinity, from twice that of sea water to freshwater (Barlow 1958). They can also withstand wide ranges in water temperature and oxygen levels. Furthermore, they can withstand unusually rapid changes in salinity, temperature, and oxygen levels. These are evidently adaptations to life in small desert pools which may dry up seasonally and are subject to flash flooding.

They are often found in pools and streams too harsh for other species. In less harsh streams, they occupy the margins and other areas which are too shallow for other fish (USFWS 1993). Pupfish are known to bury themselves in bottom debris or mud and become dormant during the winter when water temperatures are cold or during summer when water temperatures are hot. (Cox 1966)

Desert pupfish feed in the daytime on algae and small invertebrates picked off of the substrate (Moyle 1976). Eggs hatch in about 10 days, and growth is very rapid. 
Although most do not breed until the second summer, they can complete an entire life cycle in the first summer. (Moyle 1976)

In California, the desert pupfish occurs naturally in the Salton Sink. Natural streams containing pupfish include San Felipe Creek and its tributaries (i.e., Fish Creek Wash, Carrizo Wash) and associated wetlands (e.g., San Sebastian Marsh) and Salt Creek (Riverside County). Shoreline pools around the perimeter of the Salton Sea also have populations of desert pupfish (Black 1980; Lau and Boehm 1991). In addition, Lau and Boehm (1991) found desert pupfish in 72 percent of the irrigation ditches draining excess water from agricultural lands in the Imperial and Coachella Valleys. Small populations have been established through introduction at various artificial ponds at many other locations around the Salton Sink.

The only critical habitat on BLM-administered lands is San Felipe Creek and its tributaries. This critical habitat area is contained within the San Sebastian Marsh/San Felipe Creek Area of Critical Environmental Concern. San Felipe Creek is a perennial stream draining into the southwest side of the Salton Sea. Its major tributaries - Fish Creek Wash and Carrizo Wash - are intermittent streams. Portions of the streambeds and washes have a wide, open, sandy bottom. Other portions are choked with tamarisk (Tamarix sp.), cattail, and common reed (Phragmites australis). Tamarisk and arrow weed (Pluchea sericea) are common along most of the wash banks. Mosquitofish (Gambusia affinis) are also known to inhabitat the stream (Lau and Boehm 1991).

Salt Creek (Riverside County) is a perennial stream receiving its most reliable flow from artesian springs and palm oases. Occasional high water from rainfall over an extensive watershed can cause high water and flushing of vegetation and fish. Salt Creek is also infested with tamarisk. A brackish water estuary has formed where Salt Creek enters the Salton Sea. Most of Salt Creek is in the Salt Creek (Pupfish) Area of Critical Environmental Concern. The stream also contains numerous non-native fishes including tilapia (Tilapia zillii), mosquitofish, sailfin molly (Poecilia latipinna), and yellow bullhead (Ictalurus natalis) (Schoenherr 1991).

\section{Amargosa River Pupfish}

The Amargosa River pupfish is a subspecies of Amargosa pupfish (C. nevadensis). The parent species is highly variable with several subspecies identified. One subspecies, the Tecopa pupfish (C. n. calidae), was found in the same vicinity but recently became extinct. The species is in the killifish family (Cyprinodontidae). Amargosa pupfish 
was designated BLM "sensitive" in California in 1980. The subspecies is considered a species of special concern by CDFG, but it is not a candidate for Federal listing.

Although the subspecies is confined to the Amargosa River watershed in California and Nevada, they are widespread throughout this drainage and are adapted to a wide variety of aquatic habitats. They eat primarily algae, especially blue-green algae. They also eat small invertebrates, especially mosquito larvae (Danielson 1968). Growth is very rapid and sexual maturity may be reached in 4-6 weeks. Reproductive capability is very high. Populations in warm, stable springs may produce 8-10 generations per year, while those in the river may produce $2-3$ generations per year. (Miller 1948; 1961)

The Amargosa River pupfish subspecies is known primarily from two sections of the lower Amargosa River where surface flow is perennial. One above-ground section of the Amargosa River extends over the impermeable clay layers of ancient Lake Tecopa (present day Grimshaw Marsh) southward through the rocky gorge of Amargosa Canyon. The total extent is about 7 miles). The second above-ground section of river is downstream near Saratoga Springs; it is about 2 miles in length. The former flows through some lands administered by the BLM, while the latter is entirely within Death Valley National Monument administered by the National Park Service. (Williams et al. 1982; Murphy and Freas 1989)

In high seasonal flows, fish may extend downstream from Amargosa Canyon to below the confluence of Salt Creek (San Bernardino County). Individuals may reach and breed with the downstream, Death Valley population; however, Miller (1948) showed differences which suggest that the two populations are effectively isolated. High water temperatures in the summer and the drying of pools and shallows probably results in annual die-offs of sizeable proportions of the population (Soltz and Naiman 1978).

Parts of the Amargosa River are wide and heavily vegetated with marsh plants. Common plants include Goodding's black willow (Salix gooddingii), honey mesquite (Prosopis glandulosa), broad-leaved cattail (Typha latifolia), American bulrush (Scirpus americanus), rushes (Juncus spp.), and arrow weed (Williams et al. 1982). Within Amargosa Canyon, Williams et al. (1982) found that Amargosa Canyon pupfish inhabit primarily runs ( 55 percent) and pools (44 percent) with some in the riffles ( 1 percent).

Amargosa pupfish also occurs in springs and drainage ditches between Tecopa Hot Springs and the town of Tecopa. The subspecies has probably has been introduced or expanded naturally as drainage ditches were dug from the springs. Three springs containing Amargosa pupfish include Stauffer Hot Springs, Tecopa Hot Springs, and Old Thom Spring. The first two are connected at least seasonally with the Amargosa River, while the latter is not. Other similar ditches and springs between the town of 
Tecopa and Tecopa Hot Springs may contain Amargosa River pupfish. It is likely that the Amargosa River pupfish has hybridized in recent times with the Tecopa pupfish (Cyprinodon nevadensis calidae), a subspecies which is now extinct. These drainages from hot springs are relatively stable, and some warmer water is available even in winter. (Murphy and Freas 1989)

Amargosa pupfish have also been observed in Salt Creek, which drains the Silurian Valley in San Bernardino County (T. Egan, T. Rado, pers. comm.). This perennial stream is now highly choked with tamarisk.

\section{Amargosa Canyon Speckled Dace}

The speckled dace (Rhinichthys osculus) occupies a wide variety of habitats, and is one of the most widely distributed freshwater fishes in the western United States. It has a wide variety of named subspecies and forms which are confused by the high degree of natural variation and undocumented transplants. Williams et al. (1982) concluded that the population of speckled dace in the lower Amargosa River is an undescribed subspecies. Others have similarly referred to this population as unnamed $(R . o . s s p$.) (Soltz and Naiman 1978; Pister 1974). The speckled dace is in the minnow family (Cyprinidae).

The "Nevada speckled dace" population found in the lower Amargosa River was designated BLM "sensitive" in California in 1980. This population ("R. o. ssp.") is also a Category 2 candidate for Federal listing (USFWS 1991) and is considered a species of special concern by CDFG.

This subspecies inhabits the Amargosa River where it flows above ground perennially from Shoshone through Amargosa Canyon as well as Willow Creek, a major tributary in Amargosa Canyon. Although Soltz and Naiman (1978) found dace to be common in the Amargosa River near Tecopa, Williams et al. (1982) found dace to be rare in the River but common in Willow Creek. They also found them present in Willow Creek Reservoir. Ted Rado (pers. comm.) has seen the species in Salt Creek (San Bernardino County), but it may not persist there. A healthy population has also been observed at Shoshone Spring, on private land (T. Egan, pers. comm.).

The species in general prefers streams with a moderately swift current and some riffles and large pools (Soltz and Naiman 1978), but Williams et al. (1982) found the Amargosa Canyon population primarily in pools ( 87 percent) with fewer in runs (12 percent) and riffles $(<1$ percent $)$. 
Dace commonly feed at night among the rocks in loose groups. They eat primarily invertebrates found on the bottom but are known to feed on insects and zooplankton at the surface (Moyle 1976). They usually breed in their second summer, but spawning may be induced earlier by flooding, especially in intermittent streams (John 1963). They are especially adapted to high water temperatures and large diurnal temperature fluctuations. (John 1964)

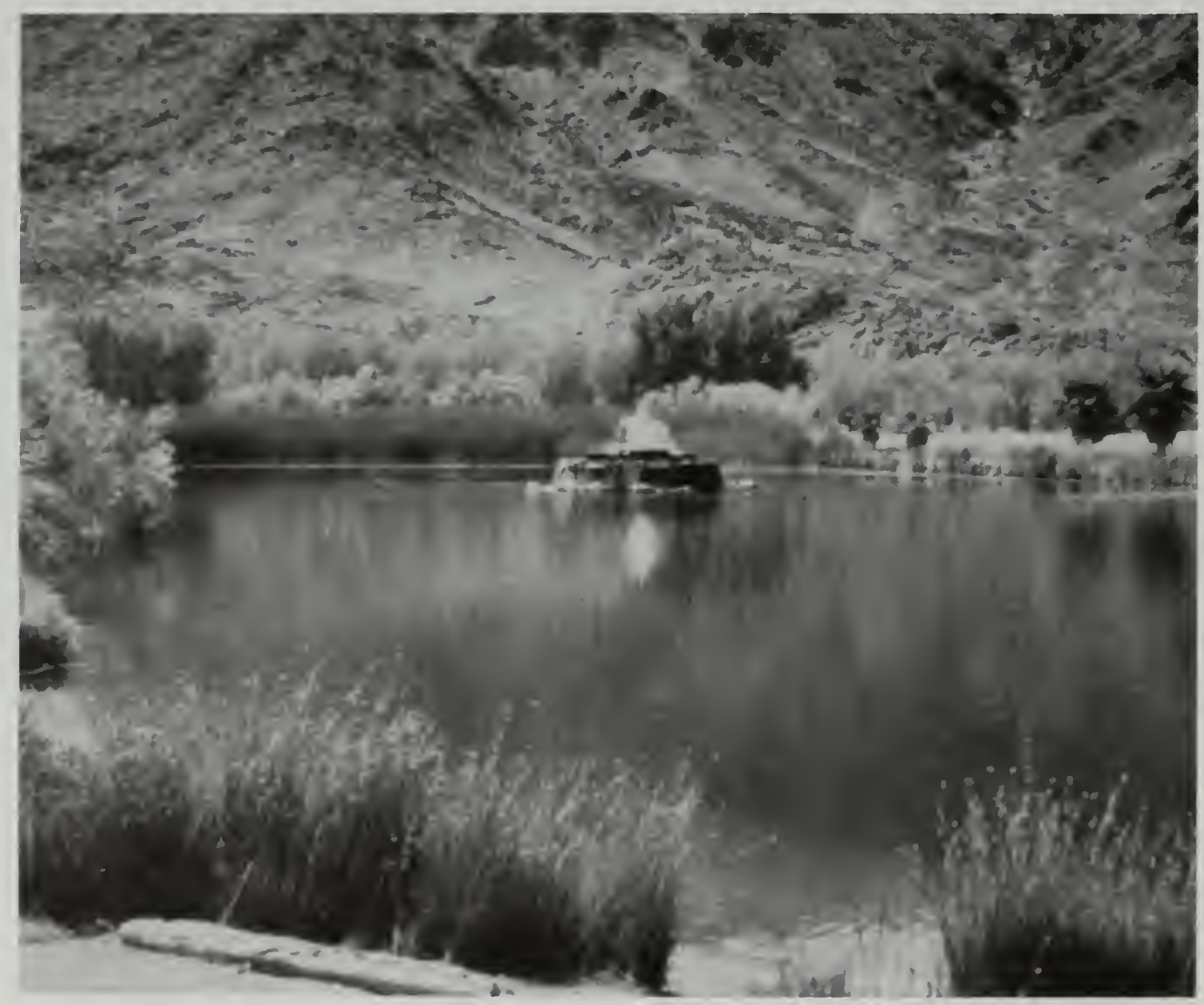

Lake Tuendae at Soda Springs provides a primary habitat for the endangered Mohave tui chub. 


\section{CURRENT AND RECENT MANAGEMENT PROGRAMS}

\section{Existing Management Plans and Recovery Plans}

All four of the special status fishes addressed in this plan fall under the California Desert Conservation Area (CDCA) Plan (BLM 1980) signed in 1980. The CDCA Plan allocated land uses and identified Areas of Critical Environmental Concern (ACEC). Five ACEC's containing habitat of special status fishes were designated in the CDCA Plan. The CDCA Plan officially designated the Amargosa River pupfish and "Nevada speckled dace" as sensitive species in California.

On a national basis, management of special status fishes is addressed in "Special Status Fishes Habitat Management" (BLM 1991a). That document is a part of the Fish and Wildlife 2000 National Strategy Plan Series. It sets forth the objectives, strategy guidance, and personnel and funding needs for the national program.

\section{$\underline{\text { Mohave Tui Chub }}$}

The first management plan for the Mohave tui chub populations at Soda Springs was prepared in March 1978 by David L. Soltz under contract (CA-060-CT7-1797) to the BLM (Soltz 1978). Building upon this, in November of that year, a "Habitat Management Plan for the Mohave Chub (Gila bicolor)" (BLM 1978) was signed by the BLM District Manager and CDFG Regional Manager.

The plan for Soda Springs was revised in January 1984 as the "Management Plan for Soda Springs - An Area of Environmental Concern and Home of the Desert Studies Center" (BLM 1984). This plan was also signed by both the BLM District Manager, CDFG Regional Manager, and Chairman of the Board of Governors of the Desert Studies Consortium as a cooperative plan under the authority of the Sikes Act (Public Law 93-452). This plan remains in effect.

In September 1984 the Regional Director of the U. S. Fish and Wildlife Service (USFWS) signed the "Recovery Plan for the Mohave Tui Chub, Gila bicolor mohavensis" (USFWS 1984). The recovery plan set forth the criteria for recovery and listed actions which should be undertaken to attain recovery. One element of the recovery plan is to "preserve and enhance existing Mohave tui chub populations and their habitats". The three existing populations listed were at Soda Springs, Desert Research Station, and China Lake Naval Weapons Center. It also called for the 
establishment of three additional secure sites in the Mojave River drainage. In the late 1980 's, a revised draft of the recovery plan was prepared; this revision had not been approved by 1993 .

The "Management Plan for the Afton Canyon Natural Area" (BLM 1989) does not include prescriptions to benefit Mohave tui chub even though the area is historic habitat. The reasons for this relate to the unstable nature of the habitat and the prevalence of arroyo chub in the river.

\section{Desert Pupfish}

In September, 1982, the "Salt Creek [Riverside County] Desert Pupfish/Rail Habitat Area of Critical Environmental Concern Management Plan" (BLM 1982a) was signed by the BLM District Manager. In December, 1986, the "San Sebastian Marsh/San Felipe Creek Management Plan" (BLM 1986) was signed by the BLM District Manager and the CDFG Regional Manager as a Sikes Act plan. These two plans set forth objectives and planned actions for the only two natural habitats of the desert pupfish in California.

In December 1993, the U.S. Fish and Wildlife Service signed the recovery plan for the desert pupfish (USFWS 1993). The recovery plan emphasizes protection of naturally occurring populations. The establishment and protection of new populations in habitats which are similar to the natural habitats is also a stated task.

ACEC plans for Dos Palmas Reserve and the Coachella Valley Preserve are in preparation. These plans will prescribe protective measures for maintenance of desert pupfish in artificial ponds on BLM-administered lands.

\section{Amargosa River Pupfish and Amargosa Canyon Speckled Dace}

In September 1983 the BLM District Manager and CDFG Regional Manager signed the "Management Plan for Amargosa Canyon Natural Area" (BLM 1983a) and "Management Plan for Grimshaw Lake Natural Area" (BLM 1983b). These two ACEC plans are cooperative plans with CDFG under authority of the Sikes Act. These plans for adjacent areas contain objectives for and planned actions benefitting both Amargosa River pupfish and Amargosa Canyon speckled dace. 
The "Management Plan for Salt Creek [San Bernardino County] Hills Area of Critical Environmental Concern" (BLM 1982c) prescribes measures to improve the habitat, but does not specifically address the needs of native fishes.

\section{Recent Habitat Enhancement and Protection}

The following lists include only those habitat enhancements and protective measures implemented since 1979.

\section{$\underline{\text { Mohave Tui Chub }}$}

\begin{tabular}{lll}
- & Deepening of Lake Tuendae (west half) & 1979 \\
Enlargement and deepening of West Pond & 1979 \\
Construction of lined pond at Desert Research & 1984 \\
$\quad$ Center at Hinckley & 1986 \\
Hiring of full-time, on-site biologist/caretaker & 1984 \\
Deepening of Lake Tuendae (west half) & 1987 \\
Construction of interpretive center & 1989 \\
Installation of new diesel pumps and & 1993 \\
$\quad$ Initiation of annual cattail pruning at MC Spring & 1992 \\
Deepening of Lake Tuendae (east half) & 1992 \\
- Enlargement and deepening of West Pond & 1992 \\
Installation of interpretive trails & 1992 \\
\hline
\end{tabular}

\section{Desert Pupfish}

- Establishment of vehicle closure around

1972

San Sebastian Marsh and vicinity

Acquisition of additional lands in San Sebastian

Marsh/San Felipe Creek ACEC

- Burning of decadent cattails and blasting of three potholes in San Sebastian Marsh

Acquisition of lands at Dos Palmas Reserve

1982,1988

Hand removal of decadent cattails at Dos Palmas

Repair of vehicle barriers at southern end of

Amargosa Canyon. 


\section{Amargosa Pupfish and Amargosa Canyon Speckled Dace}

- Establishment of vehicle closure at lower

1980 end of Amargosa Canyon

- Acquisition of lands in Amargosa Canyon and Grimshaw Marsh

1982,1988

\section{Past Relocation Efforts}

\section{$\underline{\text { Mohave Tui Chub }}$}

Miller (1968) listed two known transplants of Mohave tui chub prior to 1969. The earlier transplant in 1939 into San Felipe Creek (San Diego County) was successful for 20 years before failing. The other in 1955 into Rio Santo Tomas in Baja California also failed. Both were far from the historic range of the Mohave tui chub.

In 1969, 150 Mohave tui chub were transplanted into Piute Creek (San Bernardino County) (St. Amant and Sasaki 1971; Hoover 1983). The population survived several major storms, but the entire population was lost during a large flashflood in 1978 (Hoover 1980).

In 1970, 147 Mohave tui chub were introduced into a large, 2-acre pond at the South Coast Botanic Gardens in Palos Verdes (Los Angeles County) (St. Amant and Sasaki 1971). This was augmented with the introduction of 105 tui chub in 1975. The population was eliminated when the pond was drained in 1976. (Hoover 1980; 1983)

In 1970, Two Hole Spring (San Bernardino County) was stocked with 41 Mohave tui chub (St. Amant and Sasaki 1971). When no fish had survived in 1971, 150 more were introduced. All these died quickly. This site, managed by BLM, no longer has surface water. (Hoover 1980; 1983; T. Egan, pers. comm.)

In 1971, 400 Mohave tui chub were placed in Lark Seep Lagoon on the China Lake Naval Weapons Center (Kern County). An additional 75 tui chub were released in 1976. The population is now established and thriving. (Hoover 1980; 1983; 1986)

In 1972, 100 Mohave tui chub were released into Dos Palmas Spring and 100 more into an adjacent pond ("Shrimp Pond") (Riverside County). No population is believed to have become established. (Hoover 1980; 1983) 
In 1972 and again in 1975, tui chub were introduced into three ponds at Lion Country Safari in Laguna Hills (Orange County). No tui chub persisted. (Hoover 1980; 1983)

In 1972, 49 Mohave tui chub were released into a pond at Busch Gardens in Van Nuys and 20 into a small ornamental pond at Eaton Canyon Nature Center in Altadena (both sites in Los Angeles County). Neither population has persisted. (Hoover 1980; 1983)

In 1976, 1979, and 1981, a total of 90 tui chub were released into a small pond at the California Desert Information Center (formerly Barstow Way Station) in Barstow (San Bernardino County) (Hoover 1980; 1983). The population has had some losses, but it has persisted in small numbers. In 1992, vegetation plantings resulted in increases in population size (T. Egan, pers. comm.).

In 1978, tui chub were introduced into a small pond near Lake Norconian in Norco (Riverside County) (Hoover 1980; 1983). Apparently none have survived.

In 1978, about 16 Mohave tui chub were introduced into an artificial pond at the Desert Research Center operated by the Barstow Unified School District (Hoover 1980; 1983; T. Rado, pers. comm.). The population grew substantially and was used for studies by Barstow gifted students. The site is located near Hinckley (San Bernardino County) and is within the Mojave River drainage. In 1984 an alternate pond was constructed and lined with plastic liner to prevent encroachment by emergent vegetation. In 1991, the Barstow Unified School District abandoned the site. The pond containing tui chub then dried up, and the population was lost.

Around 1986, the Department of Fish and Game constructed two ponds at the Camp Cady Wildlife Area (San Bernardino County) adjacent to the Mojave River. After some difficulties with retaining water and with disease, Mohave tui chub are now well established in both ponds ( $\mathrm{F}$. Hoover, pers. comm.).

Of all the above, few are natural ponds or streams, and only the Camp Cady Wildlife Area is within the historic range of the species.

In 1984, Feldmeth and Soltz (1985) examined five sites (Afton Canyon Campground Pond and Railroad Pond, Owl Hole Spring, Dove Spring, Rattlesnake Spring - all in San Bernardino County) for potential use for establishment of refugia populations. They concluded that only two appeared suitable for introduction; these were Owl Hole Spring in the Owlshead Mountains and Dove Spring on the eastern slope of the San Bernardino Mountains. Potential impacts on endemic invertebrates has precluded introductions into these refugia ( $\mathrm{T}$. Rado, pers. comm.). CDFG fisheries biologists have investigated various other sites (B. Bolster, pers. comm.). 


\section{Desert Pupfish}

When the Salton Sink was inundated around 1903, the resulting Salton Sea and surrounding tributaries were colonized by naturally occurring populations of desert pupfish found in springs and seeps in the Salton Sink. In subsequent decades many agricultural drains in the Imperial and Coachella Valleys were colonized naturally. (Black 1980; USFWS 1993; Lau and Boehm 1991)

Miller (1968) listed two known transplants of desert pupfish prior to 1969 . One accidental release was at Dos Palmas Spring near the Salton Sea (Riverside County) in 1939, and the other was into a spring at Little Lake in Owens Valley (Inyo county) in 1940. The former is within the historic and present range of the desert pupfish; it's success is unknown. The second is far outside the historic range and is believed to have failed.

The desert pupfish recovery plan (USFWS 1993) was signed in December 1993. The Appendix of that document lists known relocation sites. It also lists (p. 7) the following 10 relocations in California which are known to be extant:

- The Living Desert Reserve (Riverside County); private land; introduced in 1972 into two concrete ponds; taken from the Salton Sea.

- Oasis Spring Ecological Reserve (Riverside County); owned by State of California; introduced in 1977 and 1979 into a two earthen ponds; taken from Salton Sea.

- Palm Spring in Anza-Borrego Desert State Park (San Diego County); owned by State of California; introduced in 1978 into a concrete pond; taken from Salton Sea.

- Visitor Center at Anza-Borrego Desert State Park (San Diego County); owned by State of California; introduced in 1979 into a concrete pond; taken from Salton Sea.

- Palm Canyon Refugium Pond in Anza-Borrego Desert State Park (San Diego County); owned by State of California; introduced in 1981 into a concrete pond; taken from San Felipe Creek. 
- Salton Sea State Recreation Area (Riverside County); owned by State of California; introduced in 1982 into a concrete pond; taken from Salton Sea.

- The Living Desert Reserve (Riverside County); private land; introduced in 1985 and 1987 into a third artificial, earthen pond; taken from San Felipe Creek.

- Simone/McCallum Pond at Thousand Palms Oasis (Riverside County); owned by The Nature Conservancy; introduced in 1987 into an artificial, earthen pond at a natural spring; taken from Salt Creek (Riverside County).

- Visitor Center Pond at Thousand Palms Oasis (Riverside County); owned by The Nature Conservancy; introduced in 1989 into an artificjal, earthen pond at a natural spring; taken from Salt Creek (Riverside County).

- Rancho Dos Palmas (Riverside County); owned by The Nature Conservancy; introduced in 1990 into an artificial, earthen pond; taken from Salt Creek (Riverside County).

Black (1985) reported that 75 desert pupfish were transplanted into natural habitat at San Felipe Creek (Riverside County) from Palm Canyon Refugium Pond in AnzaBorrego Desert State Park. The original stock for these fish were taken from San Felipe Creek in 1981.

\section{Amargosa River Pupfish}

Although Miller (1968) recognized the distinct population of "Nevada pupfish" present in the Amargosa River around Tecopa, he listed no transplants from that population prior to 1968. However, in a letter to Carl Hubbs in 1965, he described his release in 1941 of about 350 Amargosa River pupfish, 425 Salt Creek (Inyo county) pupfish, 143 "Apocope" or speckled dace (Rhinichthys osculus ssp.) from the San Gabriel River (Los Angeles County), and two Santa Ana suckers (Catostomus santaannae) into a pool at River Spring in Adobe Valley (Inyo County) (Miller 1965). Pupfish are now abundant in this area (P. Pister, pers. comm.).

Although probably not moved deliberately, Amargosa River pupfish have colonized the hot springs north of Tecopa and their outflows and drains. These fish probably moved into the springs as public and private baths were developed for commercial and 
recreational use in the 1950's (Soltz and Naiman 1978). The Amargosa River pupfish probably moved into most of the springs and channels naturally as drains were built, but some may have been transplanted by local residents into springs or small ponds in the immediate vicinity (Murphy and Freas 1989). The Tecopa pupfish (C. n. calidae), endemic to the hot springs, was displaced and is believed to be extinct. Murphy and Freas (1989) hypothesized that the Tecopa pupfish may have hybridized with the Amargosa River pupfish during the period of commercial development of the hot springs.

\section{Amargosa Canyon Speckled Dace}

Miller (1968) notes only one transplant of what may be Amargosa Canyon speckled dace prior to 1968. This was 10 individuals taken from the outlet of Shoshone Spring (Inyo County) in 1940. The transplant was to the "Old (Eagle) Borax Works on the west side of Death Valley." The population failed.

No other transplants are indicated in the literature or agency records. 


\section{MAJOR ISSUES}

\section{Mohave Tui Chub}

- Arroyo chub have entered the Mojave River main channel and have hybridized with the endemic Mohave tui chub.

- Current Mohave tui chub habitats are artificial and require intensive management to maintain water quality parameters within the necessary limits.

- The small number of populations in limited habitat creates a high potential for extinction due to catastrophic events.

- Mohave tui chub have been transplanted both successfully and unsuccessfully out of the natural range of the subspecies.

- The Mojave River system has been heavily modified by urbanization, water drawdown, and upstream reservoir construction.

\section{Desert Pupfish}

- Tamarisk infestations have degraded habitat quality by lowering water flow and water table levels, increasing water salinity, and decreasing overall ecosystem productivity by eliminating native plants and lowering plant diversity.

- Introduced fish species function as predators and/or competitors with native desert pupfish in both natural and artificial habitats. Among the fish introduced are the following: tilapia, mosquitofish, sailfin molly, largemouth bass (Micropterus salmoides), channel catfish (Ictalurus punctatus), black bullhead (Ameiurus melas), and carp (Cyprinus carpio).

- Artificial refugia contain small populations. As reserve stock they are subject to genetic drift or reduced variation which can decrease genetic viability (Turner 1984)

- Major portions of primary natural habitats are in private ownership and subject to modification for agriculture, etc. 
- Groundwater pumping for agriculture in areas above San Felipe Creek could reduce water flows during critical periods.

- Insecticides sprayed aerially may drift into pupfish habitat.

- Trains carrying trash to the proposed Eagle Mountain Landfill or the proposed Mesquite Landfill could spill materials harmful to pupfish into their habitat.

- The proposed lining of the Coachella Canal could reduce groundwater flows fed by canal leakage.

\section{Amargosa River Pupfish and Amargosa Canyon Speckled Dace}

- Tamarisk infestations have degraded habitat quality in the Amargosa River by lowering water flow and water table levels, increasing water salinity by denuding salts, and decreasing overall ecosystem productivity by eliminating native plants and decreasing plant diversity.

- Introduced mosquitofish may function as competitors to native desert fishes. Williams et al. (1982) thought that there was ample habitat segregation.

- Amargosa River pupfish and Amargosa Canyon speckled dace occupy much of the same habitat and are potential competitors. Williams et al. (1982) hypothesized that there was ample habitat segregation.

- Dams and diversions along the Amargosa River can alter natural flows, disturb spawning habitat, and negatively affect habitat segregation among the species present.

- Major portions of natural habitat are in private ownership and subject to modification by impoundment, diversion, channelization, etc.

- Pumping of groundwater for geothermal energy production can reduce flows at springs and alter habitats in ditches and pools dependent upon these springs. 


\section{GOALS}

The overall goals for the Special Status Fishes Strategy for the California Desert District are derived from the Fish and Wildlife 2000 Strategy Plan "Special Status Fishes Habitat Management" (BLM 1991a, p. 19); the BLM Manual 6840 on "Special Status Species" (BLM 1988, sec. .02); and the CDCA Plan, as amended (BLM 1987, p. 15):

STABILIZE AND IMPROVE

POPULATIONS OF DESERT PUPFISH

AND MOHAVE TUI CHUB ON

PUBLIC LANDS AND THE

ECOSYSTEMS ON WHICH THEY

DEPEND TO PROMOTE RECOVERY

OF THE SPECIES.

- MANAGE POPULATIONS OF

AMARGOSA RIVER PUPFISH AND

AMARGOSA CANYON SPECKLED

DACE ON PUBLIC LANDS AND THE

ECOSYSTEMS ON WHICH THEY

DEPEND TO IMPROVE THEIR

STATUS AND TO PREVENT THE

NEED FOR FEDERAL OR STATE

LISTING. 


\section{POLICY GUIDELINES AND STANDARDS}

Below is a list of policy guidelines and standards relating to the management of special status fishes. These guidelines and standards are to be followed within the California Desert District. Most are policies stated in various BLM Manuals (section .06). Some are "strategies" from the Fish and Wildlife 2000 Strategy Plan "Special Status Fishes Habitat Management" (BLM 1991a; p. 20-21).

\section{INVENTORY AND MONITORING}

- The District shall, to the extent practical, determine and monitor the occurrence and distribution of all special status fishes on public lands (BLM $1988 ;$ 1991a).

- The District shall identify all essential, historical, and potential habitat for special status fishes (BLM 1988; BLM 1991a) and shall maintain maps of this distribution (BLM 1983c, Sec. .11).

- Stream surveys shall be conducted and maintained (i.e., monitored) on public land portions of the Amargosa River, Salt Creek (Riverside County), and San Felipe Creek and its tributaries (BLM 1982b)

- Resource area offices shall maintain files containing studies and reports relating to the life history of each special status fish (BLM 1983c, Sec. $.11)$

- "Habitat sites" and "standard habitat sites" shall be used to classify habitats in order to manage them on an ecosystem basis (BLM 1990).

\section{PLANNING}

- The District shall maintain activity plans which provide for the protection and enhancement of habitat of all special status species (BLM 1988; 1991a).

- The District shall participate in the development and implementation of recovery plans for Mohave tui chub and desert pupfish (BLM 1991a; 1988). 
- The District shall ensure that all actions affecting Mohave tui chub or desert pupfish or their habitats are consistent with recovery needs and objectives (BLM 1988).

- All activity plans, including habitat management plans and ACEC plans, shall be prepared in coordination with the California Department of Fish and Game. Each activity plan should be signed by CDFG as a cooperative "Sikes Act Plan" (BLM 1981).

\section{HABITAT PROTECTION AND ENHANCEMENT}

- Natural ecosystem functions (such as water flow regimes and energy cycles) of aquatic habitats shall be maintained or restored in order to maintain biodiversity at the population, species, and ecosystem level (BLM 1991b).

- The District shall implement, to the extent possible, habitat development projects which will protect or enhance habitat of special status fishes or otherwise promote recovery of their populations (BLM 1988).

- Herbicides used to eradicate or control tamarisk or pesticides used to eradicate non-native fishes shall be applied in accordance with an approved pesticide use permit.

\section{INTRODUCTIONS}

- Non-native fishes which are adversely impacting native fishes or their habitat should be removed (BLM 1992).

- The District shall not authorize the introduction of non-native species into natural waters and shall encourage CDFG to prevent such introductions into adjacent waters (The President 1977).

- Special status fishes should be considered for transplant to suitable, unoccupied habitat, but only within the historic range of the species (BLM 1992). All such populations shall be identified as "experimental populations", as defined in the Endangered Species Act, prior to release (BLM 1992). [Note: The identification of an experimental population is similar to the "listing" process. It may not be possible to identify experimental populations due to the difficulty and lack of priority for USFWS.] 
- No release of a special status fish shall be made into habitat on public lands until a habitat management plan (or ACEC plan) has been prepared for the area. No release shall be made onto public lands without State Director's approval. (BLM 1992)

- The approval of CDFG and USFWS shall be obtained prior to the introduction or transplant of any special status fish. Other affected landowners and agencies shall also be notified. See the section on "Coordination" below. A "release plan", distinct from the habitat management plan in the previous item, shall be prepared for each release onto public lands. (BLM 1992)

\section{HABITAT ACQUISITION}

- All critical habitat or habitat essential to the maintenance or recovery of any special status fish shall be retained in Federal ownership (BLM 1988; 1991a).

- The District shall utilize its authority to acquire special status fishes habitat which needs additional protection (1991a).

\section{COORDINATION}

- As stated above, all activity plans shall be prepared in coordination with the California Department of Fish and Game, and each activity plan should be signed by CDFG as a cooperative "Sikes Act Plan" (BLM 1981).

- As stated above, no release of a special status fish shall be made into habitat on public lands until a habitat management plan has been prepared for the area. No release shall be made onto public lands without State Director's approval. (BLM 1992)

- As stated above, the approval of CDFG and USFWS shall be obtained prior to the introduction or transplant of any special status fish (BLM 1989). A "release plan", distinct from the habitat management plan in the previous item, shall be prepared for each release onto public lands. (BLM 1989).

- Projects which "may affect" Mohave tui chub or desert pupfish or its critical habitat shall receive formal consultation with USFWS as required 
by the Endangered Species Act (BLM 1988) and conference with CDFG according to the State Master Memorandum of Understanding (BLM 1983c).

- In addition, for any project which may contribute to the need to list the Amargosa River pupfish or Amargosa Canyon speckled dace (candidate species), the resource area office shall seek technical advice from USFWS (BLM 1988).

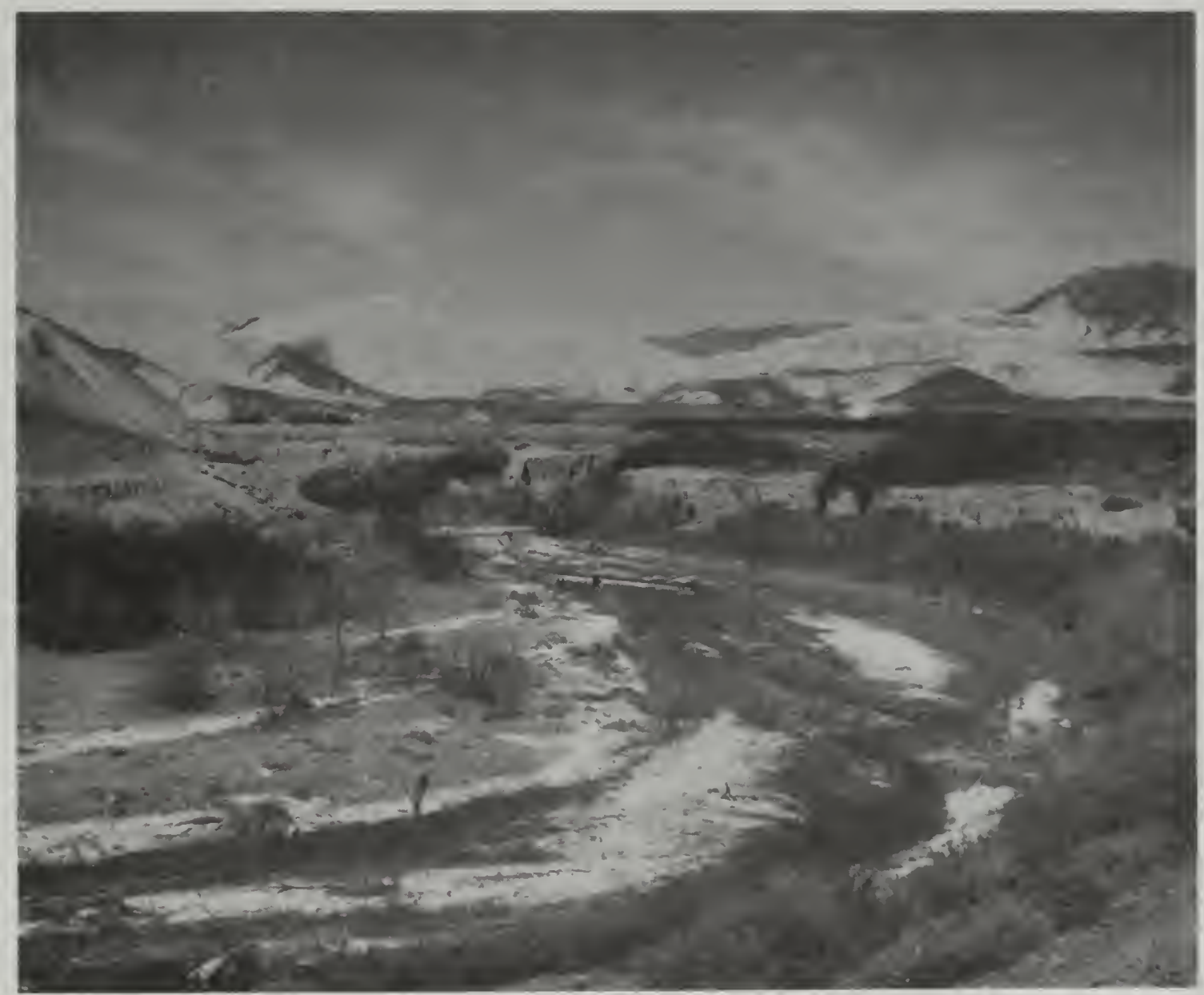

The Amargosa River near Tecopa provides habitat for both the Amargosa River pupfish and the Amargosa Canyon speckled dace. 


\section{PLANNED ACTIONS}

The following planned actions are taken from existing management plans for the various areas described (see earlier section "Existing Management Plans and Recovery Plans," p. 8ff). A few of the actions have been modified to conform with more recent information. The effects of these actions have been addressed in the environmental analyses for the management plans.

\section{Mohave Tui Chub}

\section{Soda Springs}

- Develop site as a Watchable Wildlife viewing site.

- Develop water aeration and turnover system for West Pond.

- Reintroduce Mohave tui chub into West Pond.

- Maintain open water surface at MC Spring by periodic (e.g., annual) removal of cattails.

- Dredge West Pond and Lake Tuendae as needed to provide a depth of 4-6 feet over most of ponds.

- Impede cattail encroachment over surface of Lake Tuendae through burning, cutting, or dredging.

- Operate diesel water pumps at well to maintain water level and aeration in Lake Tuendae.

- Monitor water quality in Lake Tuendae, West Pond, and MC Spring on a monthly basis. Record data on ion concentrations, dissolved oxygen, and coliform counts. Record water levels daily.

- Maintain wells and pumps in good working order. 


\section{California Desert Information Center}

- Control with hand tools the excessive growth of ditchgrass in summer months.

- Develop interpretive exhibit emphasizing management of rare fishes.

\section{$\underline{\text { Afton Canyon }}$}

- Develop the area as a Watchable Wildlife viewing site.

- Create pothole pools adjacent to the Mojave River for reestablishment of small Mohave tui chub populations.

- Construct interpretive trails to the pothole pools.

- Remove tamarisk, to the extent possible, to promote surface flow, raise water table, and improve water quality.

\section{Desert Pupfish}

\section{Salt Creek (Riverside County)}

- To establish a more reliable estimate of stream flow, reduce cattail and cane in Salt Creek between the Highway 111 Bridge and Southern Pacific Railroad bridge and move the gauging station to deeper water in this area.

- Remove tamarisk from Salt Creek and maintain tamarisk-free streamside habitat.

- Lengthen selected backwaters to increase habitat availability.

- If possible, eliminate non-native fish from Salt Creek and install drop barrier for non-native fish.

- Acquire private lands along Salt Creek and in surrounding watershed to artesian and stream flows.

- Monitor desert pupfish populations. 


\section{San Felipe Creek and tributaries}

- Monitor desert pupfish populations.

- Survey aquatic invertebrates.

- Remove tamarisk and other non-native plants, to the extent possible, from streambeds and marshes and replace with native plants.

- Maintain tamarisk-free control zones. Plant cattails and bulrush in cleared areas.

- If possible, eradicate non-native fish species (e.g., tilapia, mosquitofish) above Highway 86 Bridge.

- Construct a fish barrier if necessary to prevent the upstream movement of tilapia into desert pupfish habitat.

- Monitor precipitation.

- Monitor streamflows quarterly at selected locations to document water use.

- Monitor water quality in wells and streams. Emphasize pesticide contamination.

- Maintain open water surface at Carrizo Marsh by burning cattails and/or blasting three or four potholes. Plant cottonwoods and willows around pothole berms.

- Test feasibility of artificially created "backwaters" at Carrizo Marsh.

- In the event of a catastrophic loss, reintroduce desert pupfish from refugia populations.

- Through streamflow modeling and bank stabilization modeling, determine utility of flood control facilities.

- Acquire private lands within San Sebastian Marsh/San Felipe Creek ACEC.

- Develop and install interpretive signing to promote public support and cooperation. 


\section{Dos Palmas Springs}

- Eradicate tamarisk and other non-native plants, to the extent possible, from streambeds and marshes and replace with native plants.

- Develop site as a Watchable Wildlife viewing site.

- Monitor desert pupfish populations.

- Develop series of ponds with marginal wetlands as habitat for desert pupfish.

- Dredge ponds as needed in a cyclic manner to maintain a diversity of pond depths and aquatic plant growth patterns.

- Remove all non-native fish, to the extent possible, from desert pupfish ponds.

- Introduce desert pupfish into all ponds to be maintained for their benefit.

- Monitor water quality.

- Acquire adjacent lands containing springs and oases for possible use as desert pupfish habitat.

\section{Amargosa River Pupfish and Amargosa Canyon Speckled Dace}

\section{Amargosa River}

- Install barricades, gates, and signing to control access to desired routes.

- Develop upper Amargosa Canyon as a Watchable Wildlife viewing site.

- Provide hiking trail and interpretive signing in lower areas of Canyon to promote public cooperation and support.

- Acquire private and State lands in Amargosa Canyon to control watercourse. 
- Eradicate tamarisk, to the extent possible, from streamside and marsh areas and replace with native plants.

- Monitor recreational use to assess potential conflicts.

- Monitor water quality and surface flow annually to document use.

- Monitor riparian vegetation.

- Monitor Amargosa River pupfish, Amargosa Canyon speckled dace, and mosquitofish populations on a five-year cycle; assess trends.

\section{Salt Creek (San Bernardino County)}

- Eradicate tamarisk, to the extent possible, from streambed and replace with native plants.

- Monitor Amargosa River pupfish and Amargosa Canyon speckled dace populations on a five-year cycle; assess trends.

\section{Grimshaw Marsh and Hot Springs and Drains}

- Control vehicle access to protect natural values.

- Do not authorize geothermal activities in the vicinity to protect groundwater sources.

- Withdraw the area from Public Land laws including mining.

- Acquire private lands containing habitat of special status fishes.

- Develop upper Grimshaw Marsh area as a Watchable Wildlife viewing site.

- Eradicate tamarisk, to the extent possible, from wetland areas and replace with native species, if necessary.

- Monitor visitor use and its effects on natural values.

- Monitor populations of special status species. 


\section{PROGRAM COORDINATION}

The responsibilities of various Federal and State agencies differ in many respects; however, there is also considerable overlap. For example, while the BLM is in general a land management agency, it must know the distribution and status of special status fishes. Thus, BLM conducts or participates in inventory and monitoring efforts. While CDFG is generally regarded as a population management agency, it manages some parcels directly and often assists land management agencies in habitat development projects (e.g., pothole blasting, tamarisk eradication).

Staff expertise among the agencies differs greatly. Changes with staff assignments can result in changing expertise within an agency jurisdiction.

For these reasons, the management of special status fishes requires a coordinated effort among the public agencies and private organizations. Changing issues, staff capability, and funding make it essential that agencies cooperate to maintain a consistent and successful effort. On the next page is a table listing those agencies and organizations who have participated historically in the conservation activities for each special status fish.

Pister (1974) related how coordination challenges led to the formation of the Desert Fishes Council. This organization holds an annual symposium to aid in the transfer of research, technical, and management information relative to desert fishes.

Both the desert pupfish and Mohave tui chub have had interagency coordinating committees which have met regularly for a time and then sporadically. Membership in these coordinating committees has been informal.

In some circumstances, coordination is required by policy or law. Among these are approval of transplants, habitat management planning, and consultations and conferences. These are listed in the previous section on "Policy Guidelines and Standards" (pages 21-22). 


\section{LIST OF HISTORIC COOPERATORS}

Mohave Tui Chub

Desert Pupfish

Amargosa River Pupfish and

Amargosa Canyon Speckled Dace
Desert Studies Consortium

State Dept. of Fish and Game

U. S. Fish and Wildlife Service

Barstow Unified School District

U.S. Naval Weapons Center

The Nature Conservancy

State Dept. of Fish and Game

U. S. Fish and Wildlife Service

State Dept. of Parks and Recreation

Bureau of Reclamation

State Dept. of Fish and Game

The Nature Conservancy

U. S. Fish and Wildlife Service 


\section{REFERENCES}

Barlow, G. W. 1958. High salinity mortality of desert pupfish Cyprinodon macularius. Copeia 1958(2):231-232.

Black, G. F. 1980. Status of the desert pupfish, Cyprinodon macularius (Baird and Girard) in California. CDFG Inland Fisheries Endangered Species Pgm. Special Publ. 80-1. 42pp.

Black, G. 1985. Transfer of desert pupfish from Palm Canyon Refugium Pond (Anza [sic] -Borrego Desert State Park) to San Felipe Creek and Living Desert Reserve. Internal CDFG Memo; June 7. 1p.

Cox, T. J. 1966. A behavioral and ecological study of the desert pupfish (Cyprinodon macularius) in Quitobaquito Springs, Organ Pipe Cactus National Monument, Arizona. Ph.D. Thesis, U. of Ariz. Tucson. 102pp.

BLM. 1978. Habitat management plan for the Mohave chub (Gila mohavensis). BLM, Riverside District; Riverside, Calif. 15pp.

BLM. 1980. California Desert Conservation Area Plan. BLM, California Desert District; Riverside, Calif. 173pp.

BLM. 1981. 6780 - Habitat management plans. BLM Manual Release 6-85; 12/23/81. 34pp.

BLM. 1982a. Salt Creek desert pupfish/rail habitat management plan. BLM, California Desert District; Riverside, Calif. 18pp.

BLM. 1982b. 6671 - Stream surveys. BLM Manual Supplement - Calif. St. Off. Release 6-16; 9/9/82. 21pp.

BLM. 1982c. Management plan for Salt Creek Hills Area of Critical Environmental Concern. BLM, California Desert District; Riverside, Calif. 32pp.

BLM. 1983a. Management plan for Amargosa Canyon Natural Area. BLM, California Desert District; Riverside, Calif. 56pp.

BLM. 1983b. Management plan for Grimshaw Lake Natural Area. BLM, California Desert District; Riverside, Calif. 42pp. 
BLM. 1983c. 6840.2 - State-listed plants and animals. BLM Manual Supplement Calif. St. Off. Release 6-17; 9/26/83. 15pp.

BLM. 1984. Management plan for Soda Springs - an area of critical environmental concern and home of the Desert Studies Consortium. BLM, California Desert District; Riverside, Calif. 72 pp.

BLM. 1986. San Sebastian Marsh Area of Critical Environmental Concern management plan. BLM, California Desert District; Riverside, Calif. 87pp.

BLM. 1987. Record of decision to the 1985 plan amendments to the California Desert Plan and the Eastern San Diego County MFP. BLM Document, signed Jan. 15, 1987. 23pp.

BLM. 1988. 6840 - Special status species management. BLM Manual Release 6-116; 9/16/88. 22pp.

BLM. 1989. Management plan for Afton Canyon Natural Area and the surrounding area. BLM, California Desert District; Riverside, Calif. 66pp.

BLM. 1990. 6600 - Fish, wildlife and special status plant resources inventory and monitoring. BLM Manual Release 6-117; 8/2/90. 20pp.

BLM. 1991a. Special status fishes habitat management. BLM Rept. No. BLM/SC/PT-91/005+6844. 53pp.

BLM. 1991b. 6720 - Aquatic resource management. BLM Manual Release 6-92; 3/22/91. 18pp.

BLM. 1992. 1745 - Introduction, transplant, augmentation, and reestablishment of fish, wildlife, and plants. BLM Manual Release 1-1603; 3/26/92. 14pp.

Danielson, T. L. 1968. Differential predation on Culex pipiens and Anopheles albimanus mosquito larvae by two species of fish (Gambusia affinis and Cyprinodon nevadensis) and the effects of simulated reeds on predation. Ph.D. Thesis, Univ. of Calif., Riverside.

Hoover, F. 1980. Status of Mohave chub transplants. Internal CDFG Memo; March 26. $4 \mathrm{pp}$. 
Hoover, F. 1983. Results of Mohave chub, Gila bicolor mojavensis, relocations in California and Nevada. Calif. Fish and Game 69(1):54-56.

Hoover, F. 1986. Mohave chubs at China Lake Naval Weapons Center. Internal CDFG Memo; July 22. 2pp.

John, K. R. 1963. The effect of torrential rains on the reproductive cycle of Rhinichthys osculus in the Chiricahua Mountains, Arizona. Copeia 1963:286291.

John, K. R. 1964. Survival of fish in intermittent streams of the Chiricahua Mountains, Arizona. Ecology 45(1):112-119.

Lau, S., and C. Boehm. 1991. A distribution survey of desert pupfish (Cyprinodon macularius) around the Salton Sea, California. Rept. by Inland Fiskeries Div., Calif. Dept. of Fish and Game. 21pp.

Miller, R. R. 1948. The Cyprinodont fishes of the Death Valley System of eastern California and southwestern Nevada. Univ. Mich. Mus. Zool. Misc. Publ. 68. $155 \mathrm{pp}$.

Miller, R. R. 1961. Speciation rates in some freshwater fishes of western North America. Pp. 537-560 In F. Blair, ed. Vertebrate Speciation. Univ. Texas Press, Austin.

Miller, R. R. 1965. Letter to Dr. Carl L. Hubbs, Scripps Institute of Oceanography, dated Nov. 19, 1965.

Miller, R. R. 1968. Records of some native freshwater fishes transplanted into various waters of California, Baja California, and Nevada. Calif. Fish and Game 54(3):170-179.

Moyle, P. B. 1976. Inland fishes of California. Univ. of Calif. Press; Berkeley, Calif. 405pp.

Murphy, D. D., and K. E. Freas. 1989. Recommendations for the conservation of the Amargosa River pupfish, Cyprinodon nevadensis amargosae, and the Amargosa vole, Microtus californicus scirpensis. Rept. to The Nature Conserv. 40pp.

Pister, E. P. 1974. Desert fishes and their habitats. Trans. Am. Fisheries Soc. 103(3):531-540. 
President, The. 1977. Exotic organisms. Exec. Order 11987; May 24. 2pp.

Schoenherr, A. A. (1991). A comparison of two populations of the endangered desert pupfish (Cyprinodon macularius) - second annual report. Informal Rept. to Calif. Dept. of Fish and Game.

Soltz, D. L. 1978. Mohave chub (Gila mohavensis) at Fort Soda, California: Habitat Management Plan. BLM Contract CA-060-CT7-1797. 36pp.

Soltz, D. L., and R. J. Naiman. 1978. The natural history of native fishes in the Death Valley System. Nat. Hist. Mus. of Los Angeles Co., Sci. Series 30.

St. Amant, J. A., and S. Sasaki. 1971. Progress report on reestablishment of the Mojave chub, Gila mohavensis (Snyder), an endangered species. Calif. Fish and Game 57(4):307-308.

Turner, B. J. 1984. Evolutionary genetics of artificial refugium populations of an endangered species, the desert pupfish. Copeia 1984(2):364-369.

Turner, B. J., and R. K. Liu. 1976. The specific identity of the introduced pupfish population at Zzyzx Spring, California. Copeia 1976(1):211-212.

Vicker, C. E. 1978. Aspects of the life history of the Mohave chub, Gila bicolor mohavensis (Snyder) from Soda Lake, Calif. Thesis, Calif. State Univ. Fullerton. 28pp.

Williams, C. D., T. P. Hardy, and J. E. Deacon. 1982. Distribution and status of fishes of the Amargosa River Canyon, California. Rept. to U. S. Fish and Wildlife Service. 116pp.

USFWS. 1984. Recovery plan for the Mohave tui chub, Gila bicolor mohavensis. USFWS, Region 1; Portland, Ore. 56pp.

USFWS. 1991. Endangered and threatened wildlife and plants; animal candidate review for listing as endangered or threatened species. Fed. Reg. 56(225):58804-58836.

USFWS. 1993. Deser pupfish, Cyprinodon macularius, recovery plan. USFWS, Region 2, Phoenix, Ariz. 67pp.

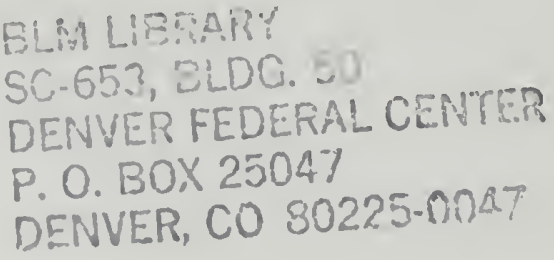





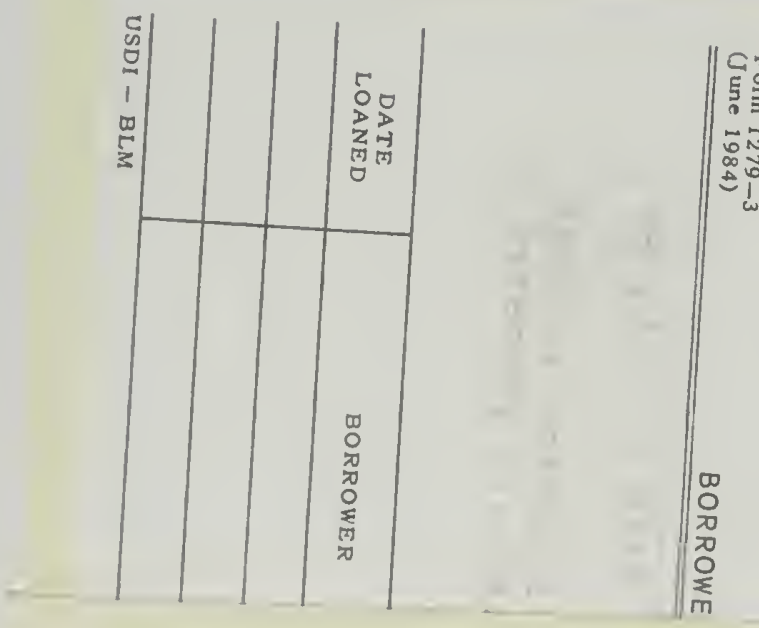




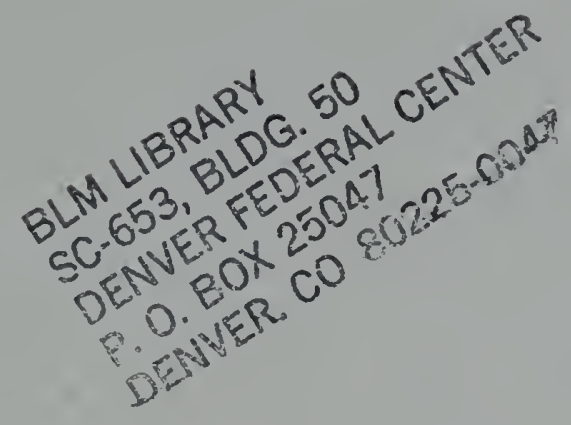




\section{California Desert District Fish and Wildlife 2000 Series}

Topic

Watchable Wildlife Strategy

Special Status Fishes Strategy

Upland Game Bird Habitat

Management Strategy

Raven Management Strategy

Neotropical (or Non-game)

Bird Strategy

Special Status Plants Strategy

Wetland/Riparian Habitat

Management Strategy

Raptor Habitat Management Strategy

Deer Habitat Management Strategy

Plant Sales and Salvage Strategy
Availability

January 1994

May 1994

In preparation

In preparation

Planned

Planned

Planned

Planned

Planned

Planned :
Technical Publication No.

BLM/CA/PT-94/007 $+\mathbf{6 5 0 0}$

BLM/CA/PL-94/012 +6500 